Research in Social Sciences

ISSN: 2641-5305

Vol. 1, No. 2, pp. 44-52

2018

DOI: $10.53935 / 2641-5305 . v 1 i 2.7$

(C) 2018 by the authors; licensee Academic Publishing Group

\section{A Cross-Linguistic Study of Super and Intensifiers in the Real World}

ABSTRACT: This study examined super in German (super) and in Mandarin Chinese (chao-ji 超級 'super' and chao 超 'super'), with data taken from corpora. We aim to test whether intensifiers function as semantically vacuous fillers, as Huddleston and Pullum (2002) proposed, and show the sociolinguistic features of intensifiers while moving toward grammaticalization. The results indicate that German super is flexible morphologically and syntactically, while super in Mandarin Chinese has several constraints. Semantically, Mandarin Chinese chao enhances the gradable property of states and chao-ji often emphasizes modern technology and events. In comparison, German super has advanced itself in terms of linguistic performance and gradually lost its role as an intensifier. The study of super and the use of intensifiers display interesting linguistic diversity and also reveal how men and women, teenagers and children play different participant roles in the process of moving intensifiers toward grammaticalization.

Key words: Intensifiers, Mandarin Chinese, German, Delexicalization, Grammaticalization, Descriptors.

\section{Introduction}

Intensifiers are modifiers that serve to enhance the word it modifies, such as super bright, where the word super, an intensifier, indicates the intensity of the brightness. Ito \& Tagliamonte (2003) found that although the most frequent intensifier is very, the use of really has spread widely among the youngest generation in the city of York in the northeast of England. Among intensifiers, Huddleston and Pullum noted that there exists a continuum in the strength of intensification from the mildest, like damn, to the strongest, like fucking (2002:558). "Super" is the intensifier we focus on in this paper, both in German and in Mandarin Chinese (hereafter Chinese), for which super in the latter is chao ji 超級 'super' or chao超 'super'.

The research goal of this paper is to test whether intensifiers function as semantically vacuous fillers, as Huddleston and Pullum (2002) proposed. In doing so, we compare the linguistic performance of super in the two languages and then approach the external sociolinguistic behaviors, in terms of e.g. gender and setting, of such intensifiers in society.

This paper is organized as follows: after the introduction, section 2 reviews related literature and introduces the methodology of the study. Subsequently, section 3 presents the roles of super in Chinese and German, starting with morphology, followed by syntax, semantics, and finally grammaticalization. Thereafter, section 4 delves into the use of general intensifiers in society, and section 5 concludes the paper.

\section{Literature Review and Methodology}

Linguists have researched intensifiers with various foci. Kaiser and Runner (2008) led experiments to investigate intensifiers in German and Dutch anaphor resolution. Pavic Pintaric (2012) determined the intensifier commonly used in fictional orality and the application of translation strategies. Greenbaum (1974) examined six verb-intensifier collocations in American and British English and concluded that each intensifier 
tended to collocate with a different kind of expression, for example, very much with expressions of favorable attitude, and badly with expressions of needing. Nevalainen and Rissanen (2002), concentrating on the adverbialization of intensifiers, compared fairly and pretty; they found that although nearly synonymous, their path to adverbialization differed.

In terms of the linguistic distribution of intensifiers, Lin's study (2001) on qualitative adjectives indicated that semantic competition influences syntactic structure. Zheng (2008) studied the development of hěn 很 'very' and suggested that its syntactic position dominated the transformation of this intensifier. Li (2006) studied super in Chinese and claimed that the abstract meaning of super was increasing. One of the counterparts of super in Chinese is fêi cháng非常 'very', which is an adjective with an adverbial usage dating from the Tang Dynasty (year 618-907) (Li 2006:165). English very and German sehr 'very' are intensifiers articulating a gradable property, while the German intensifier so conveys 'out of the blue' and combines with adjectives, nouns and verbs (Umbach 2011).

The development of super has involved lexicalization and grammaticalization. Lamarre (2013) investigated compounding patterns of the Chinese preposition wăng 'towards', and reported that wăng can be a monosyllabic localizer that appears before verbs, whereas directional complements follow verbs. Chang (2015) studied the formation of the temporal adverbs ji, bian, and jiu in Chinese. She proposed that the conjunctional functions of bian was derived from consecutive and emphatic adverbs. The semantic development and part of speech of the collocations accompany the preposition or adverbs when undergoing grammaticalization. Related research on particles can also be found. For example, Han (2014) examined modern Shanghainese $h i$ kã 'he says' and indicated that through grammaticalization, $h i$ ka has risen to the topic position to serve as a topicmarking function. In German, Smirnova (2015) took the constructional perspective, and via two case studies, considered secondary grammaticalization as a non-linear path of diachronic changes. Meanwhile, Kong (2017) investigated the development of manner of speaking markers in English and Chinese, in which grammaticalization, lexicalization as well as pragmaticalization were the concerns.

One focus of the present paper concerns the linguistic role of the intensifier super. Our data were taken from the Academia Sinica Balanced Corpus of Mandarin Chinese (Sinica Corpus, Chen and Huang 2001), the Chinese Mandarin Online Dictionary (Committee of Official Language Promotion 1998), and the German Digitales Wörterbuch der Deutschen Sprache (DWDS, Digital Dictionary of the German Language, Geyken 2013). The Sinica Corpus includes the part-of-speech tagging of the balanced Modern Chinese Corpus, and contains more than 10 million words in Modern Chinese, including genres like novels, speeches, magazines, and newspaper reports. DWDS is a continuously expanding digital dictionary system based on large electronic text corpora. This corpus is built on the six-volume dictionary of German contemporary languages (WDG) and currently contains about 100 million words. Sources includes fiction, journalistic prose, technical texts, and utility texts.

The extracted data comprise 379 tokens of chao ji 超級 ‘super', 255 of chao超 'super' and 354 of German super. The data are categorized in EXCEL with analyzing fields such as part of speech, syllable number of the collocation, meaning of the collocation, phonetic transcription (of Chinese), word-to-word translation, and frequency. The collocations of supers are essential to understand the development of super; the syllables of the collocations render supers flexibility, the part of speech and meaning provide supers pragmatic strength for evolution. We present the results as well as statistical information in the data analysis.

Two previous studies are particularly relevant to the present research. The first is by Huddleston and Pullum (2002), who treated intensifiers as semantically vacuous fillers, since intensifiers do not augment the proposition of a sentence. Instead, they only allow the speaker to express subjectivity. One group of adjectival intensifiers they examined was expressive attributives (or expletives), such as "you're a bloody genius". The expletive, as the example shows, provides little meaning to the proposition, but yields the speaker's subjectivity (agitation, distastefulness, or even approval). In addition to lexical intensification, there are two constructional intensifiers in English, i.e. repetition and tautology (2002:561). Repetition is defined as the same adjective being repeated, such as "It was a long, long way". Note that only gradable adjectives can be used in such constructions; therefore, sentences like "I hurt my left, left leg" sound odd. When tautology is employed, two synonymous adjectives are used sequentially, such as "a tiny little bird", (Huddleston \& Pullum, 2002:558). Moreover, we intend to test Huddleston's and Pullum's (2002) proposition that intensifiers function as semantically vacuous fillers.

The second study central to present research is by Ito \& Tagliamonte (2003), who investigated the usage of 
intensifiers in the York English Corpus. They took a diachronic review of related studies and also displayed the subtle development of the intensifiers. When asked about how really, which can be found in letters of the early 18th century, could become an intensifier, Ito \& Tagliamonte answered that the linguistic processes went step by step from the meaning of true, real to become a predicative adjective, just like the case of very as in the examples below (2003:269).

(i) a. The compyler here-of shuld translat veray so holy a story. (1485 OED vol 14:569, cited in Partington 1993:181)

b. For verray feere so wolde hir herte quake. (CT.F Fkl. 860)

c. He was a verray parfit gentil knyght. (Ch. CT A Prol. 72)

d. He was sike ... and was verray contrite and sorwful in his herte. (Trev. Hidg. VI 93)

(Mustanoja 1960:326)

In line with Mustanoja (1960), they also suggested that to observe the gradual development of intensifiers, one should assess their syntactic function and identify when an intensifier begins to modify predicate adjectives, which signals the intensifier has reached its last stage in development (Ito \& Tagliamonte 2003:275). In their work, they discovered a generation gap in York English, where speaking really marked the speaker as being younger in age. Following this rationale, the present research explores the use of intensifiers in society after examining the linguistic performance of super in Chinese and German.

\section{Super in Chinese and German}

This section investigates super from the aspects of Morphology, Syntax, and Semantics, as well as from a grammaticalization perspective. The discussion begins with Chinese followed by German.

\subsection{Super in Morphology and Syntax}

Let us first look at the morphological performance of super. Chinese chao can function as a mono-syllabic head (35.29\%), as in (1a) and (1b), or a bi-syllabic head (56.47\%), as in (3a); meanwhile, chao-ji is assigned to bi-syllabic $(62.37 \%)$ or multi-syllabic heads $(36.58 \%)$, such as in (3b) and (3c). In comparison, German super has no such constraints and is free to modify mono- $(2 a)$, bi- (2b) or multi-syllabic (2c) heads.

(1) In Chinese

a. Yǒu yīgè chāobàngde jùhuì 有一個超棒的聚會1 'There is a super (good) gathering.'

b. Tái sù shēng ȳi guānguāng gōngchăng rénqì chāo hāng 台塑生醫觀光工廠人氣超夯 'Formosa Biomedical Technology Corporation Health Center is super popular.'

(2) In German

a. Du bist wirklich ein super Typ. 'You are really super (guy).'

b. Das Hotel ist super zentral und man kann von da aus wirklich alles super bequem und schnell zu Fuss erreichen. 'This hotel has super location and one can really super conveniently and quickly reach everywhere on foot.'

c. Freilich könne man die atomare Schrift nur mit einem Super-Elektronenmikroskop lesen. 'Of course one can read the atomic writing only with a super electron microscope.'

Syntactically, super has regular syntactic roles in Chinese. Chao is often juxtaposed with adjectives or adjective-phrases $(33.98 \%)$, as in example (3a), whereas chao-ji can collocate with adjectives (3a), verbs (3b), and nouns (3c). Bäcklund (1973:279) found that the majority of the English intensifiers (72\%) are used with adjectival heads, and that adverbs of degree modifying nominals is a neoteric linguistic development since in the 1990s (Zhang 2000). Such a development correlates with grammaticalization, as discussed in the next section.

In German, super is flexible to collocate with nouns (4a), verbs (4b) and adjectives (4c), and can also appear in the sentence final position or act as an exclamation (4d).

\footnotetext{
${ }^{1}$ Chao and chao-ji will be referred to with their tones in examples.
} 
(3) In Chinese

a. Zhè xiăohái zhēnshi chāo (jî) kě'ài de這小孩真是超(級)可愛的 'This child is super cute.'

b. Nǐ xiànzài gēnběn chāojí huíbàole a你現在根本超級回報了啊 'Ultimately, you have been super rewarded now.'

c. Hòu sānbăi wǔshí gōng chì de chāojí dà bīngshān厚三百五十公尺的超級大冰山 'The super iceberg of 350 meters thick'

(4) In German

a. Wow, richtig gut in Szene gesetzt, das war super Licht! 'Wow, really well set in scene, that was super light.'

b. Das habt ihr super gemacht. 'You have done it well.'

c....du sprichst echt super Polnisch. '... you speak really super Polish.'

d. Der Zeitpunkt. Super! 'The timing. Super!'

As with comparatives and superlatives, intensifiers do not survive negation. The syntactic structure of the super adjective phrase is discussed in herein. Together with its head, this adjective phrase, such as (1a) chāo bàng, is a head-final compound modifier that usually takes the syntactic structure of head + chāo bàng + de (such as lǐ dà míng chāo bàng de李大明超棒的 'Li Da-Ming is super good'). The de is a modal particle, and used here for marking the attribute and emphasizing manner of the subject as though he possesses such quality. Only in the use of chao-ji can the de be omitted. When the adjective phrase is used as an exclamation, the $d e$ is optional, in which case when speaking, a pause occurs before the head and its modifier, lì dà míng chāo bàng de李大明(.)超棒的. This phonetic realization before the chao construction marks the feeling of surprise or an extra comment of the subject's attribute or manner. In terms of phonetics, the intensifier chao is usually stressed or lengthened. Nevertheless, chao can not stand alone as an exclamation as super can in German.

\subsection{Super in Semantics and Grammaticalization}

According to Shuowen jiezi (Classics of the Character Etymology, Xu, AD.100-121), chao 超 originally meant 'jump'. Jumping is a much stronger action than, for example, sitting or walking; accordingly, we can say that chao meant "intensified action". This meaning is relevant to its later semantic and syntactic development. As described in Xiandai hanyu cidian (The Contemporary Chinese Dictionary, 2002), the meaning of Chinese chao has passed through much development, and can mean (a) exceed, (b) unusual, and (c) beyond a boundary or unlimited. This suggests delexicalization because its meaning is bleaching, as further exemplified below.

With respect to German super, Duden Etymologie: Herkunftswörterbuch der deutschen Sprache (Duden Etymology: Dictionary of Origin of German Language, Drosdowski, 1997) shows that super was derived from the Latin prefix meaning über 'more than' or obendrauf 'on top'. It underwent semantic broadening by the sixteenth century, and meant sehr 'very', überaus 'exceedingly', äußerst 'ultimate', or höchst 'top most'. These meanings have been widely used since the late twentieth century due to the influence of American English. When it is used independently, it means erstklassig 'top, first class', großartig 'great', or toll 'awesome'.

In terms of adjectival collocations, both Chinese and German supers can be used to describe the quantity or quality of the head; however, Chinese chao enhances the gradable property of states $(10.80 \%)$, i.e. the degree of the temperature (5a) or convenience (5b), while chao-ji often describes modern, electronic products or skills $(27.90 \%)$, such as computer skills (5c), or natural effects like icebergs (3c) or diseases (5d). They maintain the semantic prosody of being super 'very good'.

By contrast, German super can mean 'very good' (6a), 'good' (6b), or 'actually not good' (6c-6d). The latter case usually appears as adj/adv + super formulaic with collocates such as absolut 'absolutely', echt 'really', natürlich 'naturally; of course', eigentlich 'actually', jedenfalls 'in any case', or schon 'already'. Such collocates are degree adverbs or adverbs of manner that carry the semantic prosody of 'totality' (e.g. absolutely, really, naturally); however, their truth value can vary depending on the pragmatic purpose of the speaker. In other words, the formulaic [adjective + super] can show the speaker's personal opinion, which may not coincide with the facts or may even contradict the truth value oriented by the speaker's subjectivity.

Pragmatically, super in both languages, can function as a replacement for disappointment, irony, or

Vol. 1, No. 2, pp. 44-52

2018

10.53935/2641-5305.v1i2.7 Funding: This study received no specific financial support.

Article History:
Received: 25 September 2018

Revised: 16 October 2018

Accepted: 13 November 2018

Published: 6 December 2018

() 2018 by the authors; licensee Academic

Publishing Group 
politeness, ${ }^{2}$ during which time its head can refer to atmosphere, feeling, mind, person, etc. German super has even stronger pragmatic use.

(5) In Chinese

a. Jīnnián shì chāo lěng de dōngtiān今年的冬天超冷的 'This winter is super cold.'

b. Chúchén tuō dì chāo fāngbiàn 除塵拖地超方便 'It is super convenient for dusting and mopping the floor.'

c. Měiguó zhèngfǔ jìnzhǐ yīngtè'ěr shūchū chāojí diànnǎo jìshù zhì zhōngguó美國政府禁止英特爾輸出超級電腦技術至中國 'The US government prohibits Intel from selling super computer skills to China.'

d. Nà shí bàofā chāojí liúgăn 那時爆發超級流感 'Super flu burst out at that time.'

(6) In German

a. Danke das ich bei euch super Information bekommen habe. 'Thank you that I got super information from you.'

b. Wir wurden in Schweden super empfangen. 'We were super welcomed in Sweden.'

c. Das ist theoretisch super und praktisch undurchführbar. Es funktioniert nicht. 'This is theoretically super and practically unfeasible. It won't work.'

d. Das Prinzip ist super, die Umsetzung könnte aber schwierig werden. 'The principle is super, the transformation however could be difficult.'

In Chinese, super can be used to classify the degree of manner and attribute of certain objects to express a gradable property. Be that as it may, the meaning of super has been reduced in terms of intensity and can now weaken the gradable property of the head, as in example $(5 b)$, which often means "very convenient" or just "convenient", but not necessarily "very much convenient" any more, though its positivity remains. Similarly in German, example (6a) often means "good information" or "just useful information", but not necessarily "excellent information" any more.

Although super in both languages is being delexicalized, it is especially notable in German. In terms of semantics, Chinese chao-ji often emphasizes heads that refer to modern technology and events, while German super has advanced itself in terms of linguistic performance syntactically, morphologically, semantically and pragmatically, and has gradually lost its role as an intensifier. This loss, however, can be expected as delexicalization is one of the general processes of grammaticalization (Sinclair 1992; Partington 1993).

Grammaticalization can be observed both diachronically and synchronically. One way to examine the gradual change of delexicalization is to study the patterning according to function (Mustanoja 1960:326-27). For example, Partington (1993) reported that a relationship exists between delexicalization and collocational patterns; that is, the more delexicalized an intensifier is, the more widely it collocates. To be more specific, some intensifiers favorably collocate with certain groups of lexical items, while others commonly collocate with broader choices. As demonstrated in the above discussion of Chinese chao/chao-ji and German super, it was shown that chao/chao-ji collocate with a smaller set of lexical items in comparison with German super. Partington (1993) suggested that delexicalization and "width of collocation" can be considered the same linguistic event. Thus, in comparing Chinese and German, it could be said that German super is more advanced in its delexicalization.

Furthermore, if we look back to the original meaning of chao, "jump", a verb with an independent semantic property, we can see that it had bleached long ago and has now developed into a dependent morphosyntactic element that can collocate with adjectives to intensify the degree.

Partington (1993) demonstrated that the delexicalization of awfully is advanced because its head can have positive connotations (e.g. cute, funny, and pretty) or have negative ones (e.g. boring and silly), whereas terribly tends to collocate only with negative expressions. In the case of super, both in Chinese and German, it can collocate with positive-connotation heads as in (1a), (1b), (3a), (3c), and (5b) for Chinese and (2b), (4a), and $(6 b)$ for German, as well as negative modifiers, as in (5a) for Chinese and (6c) for German. Note that (6c)

${ }^{2}$ The author would like to thank the anonymous reviewer for the insight. 
can be paraphrased as super Theory 'super theory', but it is often said as theoretisch super 'theoretically super' and with a further supplement as to why the topical subject is actually not doable. Super contains the semantic prosody positivity, however, pragmatically, super in theoretisch super functions as a replacement for disappointment in which "only super theoretically, but not practically" is expressed. The speaker's thought and feeling is thus covertly presented. The same with (6d) Das Prinzip ist super... 'The principle is super...' meaning super Prinzip 'super principle', where the head-initial structure is used for the negative connotation of the topic when put into practice. Other German examples with negative modifiers include super schlecht 'super bad', super hässlich 'really ugly', and super unwohl 'super uncomfortable', among others.

Subjectification is also apparent in the above examples in that the degree of super depends on the speaker, rather than the epistemic fact. In terms of exclamation, Super! (4d) can sometimes mean the exact opposite of super, constituting a subjectivity understood based on the correct deictic realization. Though Chinese chao/chao-ji have not yet reached this stage, it is slowly moving in this direction. Zhang (2000) reported three phases of grammaticalization mechanisms for Chinese adverbs: initially, content words like nouns or verbs transform into adverbs; then, the internal structure of the adverb bleaches; and, finally, the adverb undergoes further bleaching and becomes a functional marker, such as a conjunction and an interjection. Accordingly, from a verb meaning 'jump' to acting as an intensifier, it is clear that Chinese chao/chao-ji is on the move.

We can thus declare that super in both Chinese and German is undergoing grammaticalization, with German super being more advanced in its evolution.

\section{Discussion: Intensifiers in Society}

We now examine the external factor that generates the development of intensifiers, namely, society. The social factors involve the person, gender, age, education and setting. Umbach (2011) found in the novel she investigated that intensifiers were used particularly when adults talk to youngsters. "Neutral" intensifiers like $z u$ Tode 'to death' also appeared, such as zu Tode langweilen 'bored to death'. The novel reflects the social tendency that when adults talk to children, intensifiers are often used for hyperbolic effect to draw children's attention. On the other hand, Labov (1985:44) noted that really is one of the most frequently used intensifiers in colloquial discourse in American English. Speakers tend to utter the intensifier really in informal or familiar conversation rather than in formal speech or writing. Similarly, Stenström (1999) also found that really is the most popular intensifier of adjectives among teenagers in London.

Ito \& Tagliamonte (2003) investigated very and really in British English to identify the interface between education and gender in using really (see Fig. 1). They not only found that younger and more educated women tended to use really more, they also discovered that there is a relationship in terms of gender and education and the use of the intensifier in the middle-aged generation, where less educated young men seldom use really, as shown by the arrow in the Figure.

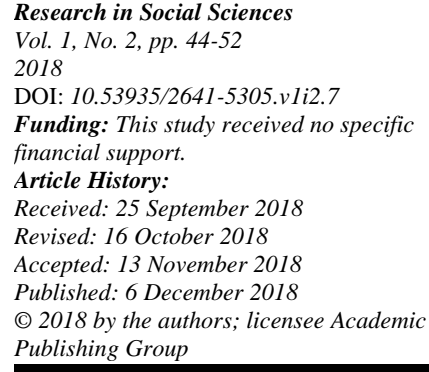

| 49

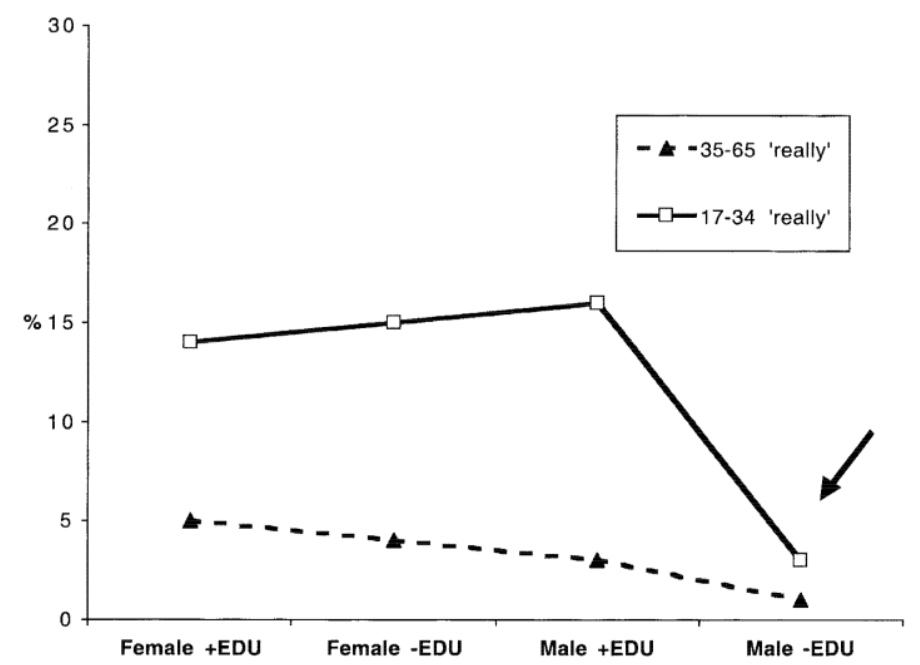

Fig-1. Distribution of really by age, gender, and education (Ito \& Tagliamonte 2003: 276)

Additionally, Fig. 1 indicates that females (either +educated or -educated) tend to use really more than 
male speakers do. In Ito and Tagliamonte's words, "women lead in the change from one intensifier to another" (2003:277). Ito \& Tagliamonte even pointed out that it is at the time when "the newcomer expands in function" (2003:277); that is to say, newcomers like to use intensifiers like really as hyperbole to draw attention. Stoffel (1901) and Jespersen (1922) noted in their studies from roughly a hundred years ago that ladies are fond of saying He is $\underline{s o}$ charming!, and It is $\underline{s o}$ lovely!. Stoffel realized in 1901 that gender is an essential factor that influences the use of intensifiers. A direct quotation from his examination is that "ladies are notoriously fond of hyperbole" (Stoffel 1901:101). Two decades later, Jespersen (1922:250) confirmed that "The fondness of women for hyperbole will very often lead the fashion with regard to adverbs of intensity". As such, the leading role of female speakers in the development of intensifiers has been identified for many years.

Age plays a role as well. Ito and Tagliamonte further stated that "In fact, the younger educated males are just as likely to use really as the women" (2003:277). In addition, they discovered a significant generation gap in York English: the intensifier very is used by the generation aged over 35 while younger people tend to use really. For the younger generation with "right" topics and settings, intensifiers are used with high frequency, which accords with Peng (2009:83), who indicated that intensifier expressions are uttered particularly by youth when they act in a pettishly charming manner or show emotions in colloquial talk. However, these intensifier expressions do not appear in written form, and are only colloquialisms. There is an increase in intensification across generations, for example, in Taiwan guài 怪 'strange', kuáng 狂 ‘crazy', and bào 爆 'explode' are used among the youth in expressions like guài rè de 怪熱的 'quite hot', hěn kuáng 很狂 'just super, crazy', bào è 爆餓 ‘very hungry’, or bào hăo chī 爆好吃 'very delicious'. Recent innovations include hěn liū 很六 'very six', hăo liū 好六 'good six' and niúbī牛B 'cattle B' all of which mean 'someone or something is really good'. The same evolution is happening with German super, which is now losing its emphasizing tone. Accordingly, instead of super gut 'super good', the following are often used: voll gut, mega gut, krass gut, total gut, endgut, cool gut, tiptop, todschick hamma, hammer, spitze and genial, which all mean 'super good'. Even an "endearment" form, supi 'super good' has developed among girls.

One interesting phenomenon is also that old and new intensifiers compete with each other. Bolinger (1972:18) observed this phenomenon and noted that as each new intensifier "has appeared on the scene it has elbowed the other aside." Meanwhile, previous preferences do not simply die out; rather, they remain used in specific (syntactic, pragmatic) contexts, and the newcomer never takes over the whole linguistic territory as a substitute intensifier.

Intensifiers in society have their unique movement and natural development for which no specific speakers can dictate their change. Nevertheless, particular groups of speakers do dominate their development naturally and tactfully in specific settings.

\section{Conclusion}

In this paper, we investigated super from the aspects of morphology, syntax, and semantics, as well as from a grammaticalization perspective. In closing, the development of intensifiers as generated by society was presented.

We found that (1) morphologically: Chinese chao-ji is assigned for bi- or multi-syllabic heads with chao being for mono-syllabic heads as well. German super has no such constraint. (2) Syntactically: German super is flexible in collocating with nouns, verbs or adjectives (e.g. super Licht, echt super), whereas Chinese chao only juxtaposes with adjectives and chao-ji with nouns (e.g. chāo ji dà bīng shān 超級大冰山 'super iceberg') and verbs (chāo jí huí bào 超級回報 'super reward'). German super can also appear in the sentence final position or act as an exclamation (Super!). (3) Semantically: both Chinese and German super can be used to describe the head in terms of quantity or quality. While Chinese chao enhances the gradable property of states (chāo lěng 超冷 'super cold'), chao-ji mostly describes modern, electronic products or skills, natural effects or diseases. In contrast, German super can mean 'very good', 'good', or 'actually not good' (a pragmatic substitute for disappointment, irony, politeness, e.g. theoretisch super), and its heads can refer to atmosphere, feeling, mind, person, etc. As a result, in terms of grammaticalization, the development of super in German is more advanced than in Chinese due to its broader collocation width.

The results further indicate that, semantically, while Chinese chao-ji often emphasizes modern technology and events; German super has advanced itself in terms of linguistic performance syntactically, morphologically, and semantically and has gradually lost its role as an intensifier. On this point, we agree with Huddleston and

Research in Social Sciences
Vol. 1, No. 2, pp. 44-52

2018

Funding: This study received no specific

financial support.

Article History:
Received: 25 September 2018

Revised: 16 October 2018

Accepted: 13 November 2018

Published: 6 December 2018

(C) 2018 by the authors; licensee Academic Publishing Group

$\mathbf{5 0}$ 
Pullum (2002) that intensifiers function as semantically vacuous fillers. In addition, we propose that intensifiers have a special semantic function that allows syntactic flexibility as well as pragmatic participation.

The external factors involved in the development of intensifiers in society were presented as well. Intensifiers are favored by different speakers of different ages and gender in various settings. Teenagers, women and younger educated males are fond of using intensifiers. In some settings, intensifiers are particularly popular, such as in colloquial conversation to keep up with the current fad, to draw the hearer's attention or when adults talk to young children. Once an intensifier is accepted by a language community and is used frequently, it can be said that grammaticalization has begun.

The use and development of intensifiers display interesting linguistic phenomena, and show not only language diversity but also similar linguistic development.

\section{Data Sources}

Chen, Keh-Jiann and Huang, Chu-Ren (陳克健, 黃居仁). 2001. Academia Sinica Balanced Corpus of Mandarin Chinese Version 4.0, Taipei: Academia Sinica.

Committee of Official Language Promotion (Ed.). 1998. Chinese Mandarin Online Dictionary, (3 ${ }^{\text {rd }}$ Ed.) Taipei: Ministry of Education.

Drosdowski, Günther (Ed.). 1997. Duden (Band 7) Etymologie: Herkunftswörterbuch der deutschen Sprache. Mannheim. Leipzig; Wien; Zürich: Dudenverlag.

Geyken, Alexander. 2013. Digitales Wörterbuch der deutschen Sprache (DWDS), Berlin: BerlinBrandenburgische Akademie der Wissenschaften.

\section{References}

Bäcklund, Ulf. (1973). The collocation of adverbs of degree in English. Uppsala: Almqvist \& Wiksell.

Bolinger, Dwight. (1972). Degree words. The Hague, Paris: Mouton.

Bybee, L. Joan, Revere D Perkins, William Pagliuca. (1994). The Evolution of Grammar: Tense, aspect, and modality in the languages of the world. Chicago: University of Chicago Press.

Chang, Li-Li (張麗麗). (2015). The formation of the temporal adverbs ji, bian, and jiu. Language and Linguistics, 16(2): $139-168$.

Chinese Academy of Social Sciences Research Institutes of Language Department of Dictionary (Ed.). (2002). Xiandai hanyu cidian 現代漢語詞典 (The Contemporary Chinese Dictionary), (4 ${ }^{\text {th }}$ Ed.). Bejing: The Commercial Press.

Greenbaum, Sydney. (1974). Some Verb-Intensifier collocations in American and British English. American Speech, 49 (1/2): 79-89.

Han, Weifeng, Shi Dingxu. (2014). The evolution of $\mathrm{hi}^{23} \mathrm{ka}^{34}$ ('he says') in Shanghainese. Language and Linguistics, 15 (4): 479-494.

Huddleston, Rodney D., Geoffrey K. Pullum. (2002). Adjectives and adverbs. The Cambridge Grammar of the English Language. Cambridge: Cambridge University Press.

Ito, Rika, Sali Tagliamonte. (2003). Well weird, right dodgy, very strange, really cool: layering and recycling in English intensifiers. Language in Society, 32(2): 257-279.

Jespersen, Otto H. (1922). Language: Its nature, development, and origin. London: George Allen \& Unwin.

Kaiser, Elsi, Jeffrey T. Runner. (2008). Intensifiers in German and Dutch Anaphor Resolution. Proceedings of the $27^{\text {th }}$ West Coast Conference on Formal Linguistics. Natasha Abner \& Jason Bishop, eds. Somerville, MA: Cascadilla Proceedings Project. 265-273

Kong, Lei, Qin Hongwu. (2017). The development of manner of speaking markers in English and Chinese: Pragmaticalization, grammaticalization and lexicalization. Journal of Pragmatics, 107: 16-30.

Labov, William. (1985). Intensity. Meaning, form and use in context: Linguistic applications. Deborah Schiffrin, ed. Washington: Georgetown University Press. 43-70.

Lakoff, George. (1987). Women, fire, and dangerous things: What categories reveal about the mind, Chicago: University of Chicago Press.

Lamarre, Christine. (2013). When lexicalization meets grammaticalization: the development of 'wang+path' adverbials in northern Chinese. Breaking Down the Barriers: Interdisciplinary Studies in Chinese linguistics and beyond, volume II. Taipei: Institute of Linguistics, Academia Sinica. 887-909.

Li, Li-ying. (2006). Latest usage of 'chaoji'. Journal of Hunan University of Science and Engineering, 27(6): 164-165.

Lin, Hsien-chu. (2001). A semantic study of Chinese degree adjcetives in collcation:take examples from 'da', 'gao', 'duo', 'shen', 'qiang', M.A. Dissertation. Department of Chinese Teaching, National Taiwan Normal University, Taipei.

Mustanoja, F. Tauno. (1960). A Middle English syntax. Helsinki: Société Néophilologique. 
Nevalainen, Terttu, Matti Rissaene. (2002). Fairly pretty or pretty fair? On the development and grammaticalization of English downtoners. Language Sciences, 24(3): 359-380.

Partington, Alan. (1993). Corpus evidence of language change: The case of intensifiers. Text and technology: In honour of John Sinclair. Mona Baker, Gill Francis \& Elena Tognini-Bonelli, eds. Amsterdam, Philadelphia: John Benjamins. $177-92$.

Pavic Pintaric, Anita. (2012). Translating intensifiers in dialogues of German and Croatian young adults' literature Translating fictional dialogue for children and young people. Martin B Fischer \& Maria Wirf Naro, eds. Berlin: Frank and Timme. 235-249.

Peng, Yan (彭燕). (2009). Comparing of the adverbs guai 怪, hen 很, shifen 十分, tai 太, feichang 非常, Journal of Sanmenxia Polytechnic, 8 (1): 82-84.

Sinclair, John. (1992). Trust the text: The implications are daunting. Trust the text: The implications are daunting (Advances in systemic Linguistics: Recent theory and practice.) Martin Davies \& Louise Ravelli, eds. London, Pinter. 5-19.

Smirnova, Elena. (2015). When secondary grammaticalization starts: a look from the constructional perspective. Language Sciences, 47: 215-228.

Stenström, Anna-Brita. (1999). He was really gormless - She's bloody crap: Girls, boys and intensifiers. Out of corpora: Studies in honour of Stig Johansson. Hide Hasselgård \& Signe Okesfjell, eds. Amsterdam, Atlanta: Rodopi. 6978.

Stoffel, Cornelis. (1901). Intensives and down-toners. Heidelberg: Carl Winter.

Traugott, Elizabeth Closs, Bernd Heine. (1991. Introduction. Approaches to grammaticalization: Focus on theoretical and methodological issues. Elizabeth Closs Traugott \& Bernd Heine, eds. Amsterdam, Philadelphia: John Benjamins. $2-14$.

Umbach, Carla. (2011). Intensifiers and measure phrases combined with verbs. M.A. Thesis of Institute of Cognitive Science. Düsseldorf: Heinrich Heine Universität Düsseldorf.

Xu, Shen (許慎). AD. (1992). Shuowen jiezi (說文解字 Elucidations of the signs and explications of the graphs). Beijing: Zhonghua shuju.

Zhang, Yi-sheng (張誼生). (2000). On grammaticalization mechanisms of Chinese adverbs. Zhongguo Yuwen, $274:$ 3-15.

Zheng, Hong (鄭宏). (2008. Study on the formation of 'hen(很)', Journal of Shaogian University, Social Science 29, (11): 100-102.

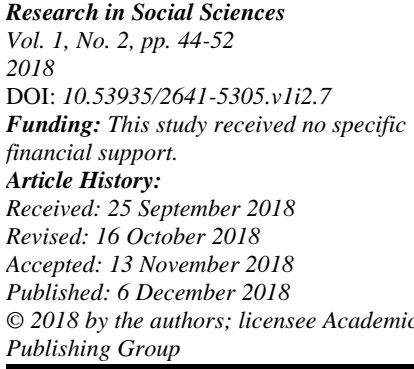

